\title{
Bacterial Polysaccharide and Sorbitol in Fireblight Exudate
}

\author{
By S. J. EDEN-GREEN* AND M. KNEE \\ East Malling Research Station, East Malling, Maidstone, Kent, MEI9 6BJ
}

(Received 23 August 1973; revised I3 November 1973)

INTRODUCTION

The exudation of gum-like bacterial masses from diseased regions is a frequent feature of fireblight [Erwinia amylovora (Burrill) Winslow et al.] and other bacterial plant diseases. Exudate usually appears on the plant surface as small globules, a spreading film, or occasionally as fine aerial strands (Eden-Green \& Billing, 1972; Billing \& Eden-Green, 1973) and may provide a source of inoculum when transported by wind or wind-blown rain. Emergence of exudate follows the development of extensive internal bacterial populations, sometimes before other disease symptoms (wilt or necrosis) appear (Gowda \& Goodman, 1970). Since bacteria account for only about $20 \%$ of the dry weight of exudate removed from plant surfaces, analysis of the substantial non-bacterial moiety is of interest in view of the physical properties involved in the formation of aerial strands and its possible role in disease physiology.

\section{METHODS}

Potted apple, pear and hawthorn plants were inoculated with Erwina amylovora by needle puncture of the stem below the tip of a growing shoot, or by cutting off the apices of recently unfolded leaves with scissors dipped in inoculum (Eden-Green, 1972). Exudate from a particular host species was removed with a small blade within 2 or 3 days of its emergence, bulked and stored in vacuo over $\mathrm{P}_{2} \mathrm{O}_{5}$. Bacteria were removed from $\mathrm{I} \%(\mathrm{w} / \mathrm{v})$ aqueous solutions of exudate by centrifugation $(25000 \mathrm{~g})$ followed by membrane filtration.

Preliminary analyses indicated that the principal constituent of each bacterium-free sample was polysaccharide; this was precipitated from $80 \%(\mathrm{v} / \mathrm{v})$ ethanol solution on the addition of a few drops of saturated $\mathrm{CaCl}_{2}$, and formed the bulk of an ' $80 \%$ ethanolinsoluble' fraction. The latter was hydrolysed with $0.8 \mathrm{~N}^{-\mathrm{H}_{2}} \mathrm{SO}_{4}$ in an autoclave at $12 \mathrm{I}{ }^{\circ} \mathrm{C}$ and neutralized with $N, N$-bis-octylmethylamine (Stoddart, Barrett \& Northcote, 1967). Uronic acid present in hydrolysates was identified by paper chromatography (Fischer \& Dörfel, 1955) and estimated colorimetrically (Bitter \& Muir, 1962; Knee, 1973); neutral sugars were identified and estimated by gas-liquid chromatography of their trimethyl-silyl derivatives (Holligan \& Drew, I97I ; Knee, I973). The polysaccharide was further characterized by chromatography on columns of DEAE cellulose in the phosphate form and Sephadex G-200 (Knee, 1973).

Between 20 and $50 \%$ of the exudate matrix was soluble in ethanol. Carbohydrates in this ' $80 \%$ ethanol-soluble fraction' were analysed by gas chromatography of acetate derivatives (Holligan \& Drew, 197I) on a 2 m column of $2 \%$ Silicone Fluid FS I 265 (QFI) on Chromosorb $\mathrm{G}$ at $190^{\circ} \mathrm{C}$, and trimethyl-silyl derivatives as above.

* Present address: O.D.A. Lethal Yellowing Research Team, Coconut Industry Board, P.O. Box 204, Kingston Io, Jamaica, West Indies. 
Table I. Composition of $80 \%$ ethanol-insoluble fractions of exudate samples from fireblight-infected host plants and from culture filtrates of Erwinia amylovora

\begin{tabular}{|c|c|c|c|c|}
\hline \multirow[b]{2}{*}{ Sample } & \multicolumn{4}{|c|}{ Constituents ( $\%$ total accounted for): } \\
\hline & Galactose & Glucose & Mannose & Uronide \\
\hline \multicolumn{5}{|l|}{ Exudate samples: } \\
\hline Apple & $74 \cdot 7$ & $6 \cdot 5$ & $2 \cdot 5$ & $16 \cdot 3$ \\
\hline Pear & $74 \cdot 1$ & 6.6 & $2 \cdot 6$ & $16 \cdot 7$ \\
\hline Hawthorn & $74 \cdot 9$ & $6 \cdot 3$ & $2 \cdot 6$ & $16 \cdot 2$ \\
\hline \multicolumn{5}{|l|}{ Culture filtrates:* } \\
\hline YPA+ sorbitol & $69 \cdot 0$ & $7 \cdot 8$ & $0 \cdot 8$ & $22 \cdot 4$ \\
\hline YPA+glucose & $58 \cdot 3$ & $10 \cdot 3$ & $7 \cdot 6$ & $23 \cdot 8$ \\
\hline YPA + galactose & $63 \cdot 5$ & $8 \cdot 7$ & $5 \cdot 1$ & $22 \cdot 7$ \\
\hline
\end{tabular}

* Extracted from bacterial growth removed from Oxoid yeast extract + peptone agar (YPA) with carbohydrate added to I $\%(w / v)$ after autoclaving.

To test the phytotoxic effects of exudate, apple fruit and potato discs were incubated in concentrated $(9 \mathrm{mg} / \mathrm{ml})$ aqueous solutions, and apple shoot tip cuttings were placed in dilute $(5 \mu \mathrm{g} / \mathrm{ml})$ aqueous solutions (Hildebrand, I939; Pierstorff, I93I).

\section{RESULTS AND DISCUSSION}

Galactose was the major neutral monomer detected in the $80 \%$ ethanol-insoluble fractions with small amounts of glucose and mannose; the uronic acid had similar mobility to glucuronic acid on a paper chromatograph. The polysaccharides from three host sources had very similar monomeric compositions (Table I). Polysaccharides with rather similar composition were extracted from the bacterial growth on plates of yeast extract and peptone agar with various carbohydrate supplements (Table I). This, and the similarity of composition with extracellular polysaccharides produced by other Enterobacteriaceae (Sutherland, 1972) and bacterial plant pathogens (Sutton \& Williams, 1970) indicated a bacterial origin for the fireblight-exudate polysaccharide.

The polysaccharide and a small amount of protein in the $80 \%$ ethanol-insoluble fraction were both excluded from a Sephadex G-200 column. Polysaccharide and protein were retained by DEAE cellulose but were separated by elution with a phosphate gradient. The polysaccharide eluted at the higher ionic strength as a single peak containing neutral and acidic residues. This indicated that the $80 \%$ ethanol-insoluble fraction contained a single heteropolymer which was a polysaccharide and not a glycopeptide, of the kind known to have phytotoxic effects when produced in infections of plants by other bacterial species (Strobel, 1972).

Concentrated aqueous solutions of bacterium-free exudate had no toxic effect on apple fruit or potato discs as judged by neutral red staining (Fushtey, 1957), but dilute solutions induced rapid wilting in apple shoot tip cuttings, which recovered in water if lower stem sections were removed. Bacteria are rarely seen in the xylem of diseased stems, however, and demonstration of the direct involvement of exudate polysaccharide in the wilting which often accompanies fireblight infections will depend on further investigation of the presence of this polysaccharide in these tissues.

Sucrose and other sugars could be detected in $80 \%$ ethanol-soluble fractions but the major constituent was a hexitol whose acetate derivative had a similar retention time to that of sorbitol on QFI. This material accounted for $28 \%$ of the dry weight of exudate from the apple sample. 
Sorbitol is known to be the principal translocatory carbohydrate in apple (Bieleski, 1969) and other Rosaceae (Zimmerman, I969), and it seems likely that the large quantities found in the ethanol-soluble fraction were derived directly from the host. Sorbitol is readily metabolized in vitro by Erwinia amylovora, however, and its predominance in exudate suggests that it is available in excess of demand, as might be the case if the pathogen had access to translocatory material in the phloem. Despite recent reports of bacterial migration in these tissues (Gowda \& Goodman, 1970; Lewis \& Goodman, 1965) based on the results of ringing experiments, careful histological examinations by many previous workers have shown that bacterial colonization of stem tissues is largely confined to cortical parenchyma, at least in the early stages of disease. Invasion of phloem has rarely been reported. It is not known whether radial movement of sorbitol from phloem to cortical parenchyma could account for the quantities found, or whether sufficient amounts are available in these tissues themselves. An alternative possibility is that sorbitol production is stimulated locally in response to the pathogen.

Advice and discussion provided by Dr E. Billing are gratefully acknowledged. This work was done during the tenure (by S. E.-G.) of a V. H. Blackman Research Studentship and forms part of a thesis for the degree of Ph.D. at the University of London.

Note added in press. R. N. Goodman, J. S. Huang and P. Huang at the Second International Congress for Plant Pathology, Minneapolis, Minnesota, U.S.A. (5 to 12 September 1973) reported the isolation of a polysaccharide from fireblight-infected slices of pear fruits. The preparations contained a small amount of protein and the only monosaccharide detected in hydrolysates was galactose. From observations of the degree of wilting induced by this material in various plant species the authors suggested that it was a host-specific toxin with effects proportional to the field susceptibility of plant species.

\section{REFERENCES}

BiELESKI, R. L. (1969). Accumulation and translocation of sorbitol in apple phloem. Australian Journal of Biological Sciences 22, 6I I-620.

Billing, E. \& Eden-Green, S. J. (1973). Bacterial strands on hawthorn: glasshouse and field observations. In East Malling Research Station Report for 1972, pp. 166-168.

Bitter, T. \& Muir, H. M. (1962). A modified uronic acid carbazole reaction. Analytical Biochemistry 4, 330-334.

EDEN-GREEN, S. J. (1972). Studies in fireblight disease of apple, pear and hawthorn (Erwinia amylovora (Burill) Winslow et al.). Ph.D. Thesis, University of London.

Eden-Green, S. J. \& Billing, E. (1972). Fireblight: occurrence of bacterial strands on various hosts under glasshouse conditions. Plant Pathology 21, I 2 I-1 23.

FiSCHER, F. G. \& DöRfEL, H. (I955). Die papierchromatographische Trennung und Bestimmung der Uronsäuren. Hoppe-Seyler's Zeitschrift für physiologische Chemie 30r, 22 I-234.

FushteY, S. (I957). Studies on the physiology of parasitism. XXIV. Further studies on the killing of plant cells by fungal and bacterial extracts. Annals of Botany 21, 273-286.

Gowda, S. S. \& Goodman, R. N. (1970). Movement and persistence of Erwinia amylovora in shoot stem and root of apple. Plant Disease Reporter 54, 576-580.

Hildebrand, E. M. (1939). Studies on fireblight ooze. Phytopathology 19, I42-I 58.

Holligan, P. M. \& DrEw, E. A. (I97I). Routine analysis by gas liquid chromatography of soluble carbohydrates in extracts of plant tissues. II. Quantitative analysis of standard carbohydrates, and the separation and estimation of soluble sugars and polyols from a variety of plant tissues. New Phytologist 70, 27 I-297.

KNEE, M. (1973). Polysaccharides and glycoproteins of apple fruit cell walls. Phytochemistry 12, $637-653$. 
LEwIs, S. \& Goodman, R. N. (1965). Mode of penetration and movement of fireblight bacteria in apple leaf and stem tissue. Phytopathology 55, 719-723.

PierstorfF, A. L. (193I). Studies on the Fireblight Organism, Bacillus amylovorus. Cornell University Memoir No. 136.

Stoddart, R. W., Barrett, A. J. \& Northcote, D. H. (1967). Pectic polysaccharides of growing plant tissues. Biochemical Journal ro2, 194-204.

Strobel, G. A. (1972). Comparative biochemistry of the toxic glycopeptides produced by some plant pathogenic corynebacteria. In Proceedings of the Third International Conference on Plant Pathogenic Bacteria, I97I, pp. 357-365. Edited by H. P. Mass Geesteranus. Wageningen: Pudoc.

SUTHERLAND, I. W. (1972). Bacterial exopolysaccharides. In Advances in Microbial Physiology, vol. 8, pp. I43213. Edited by A. H. Rose and D. W. Tempest. London: Academic Press.

Sutton, J. C. \& Williams, P. H. (1970). Comparison of extracellular polysaccharides of Xanthomonas campestris from culture and from infected cabbage leaves. Canadian Journal of Botany 48, 645-65I.

Zimmerman, M. (1969). The translocation of nutrients. In The Physiology of Plant Growth and Development, pp. 383-417. Edited by M. B. Wilkins. London: McGraw-Hill. 